\title{
Pengembangan Aplikasi Belajar Online Berbasis Web Menggunakan Waterfall
}

\author{
Afif Wijang Wahid Ramadhan ${ }^{1}$, Dhoifullah ${ }^{2}$, Husen $^{3}$, Candra ${ }^{4}$, Sri Mulyati ${ }^{5}$ \\ Teknik Informatika, Universitas Pamulang, Tangerang Selatan, Indonesia, 15417 \\ e-mail: 1afiframdhan1234@gmail.com, ${ }^{2}$ doifullah73@gmail.com, ${ }^{3}$ husenmaulana51@gmail.com, \\ ${ }^{4}$ candradanuartacfc@gmail.com, ${ }^{5}$ dosen00391@unpam.ac.id
}

Submitted Date: April 05 ${ }^{\text {th }}, 2021$

Revised Date: April 12 $2^{\text {th }}, 2021$
Reviewed Date: April $11^{\text {th }}, 2021$

Accepted Date: July 06 ${ }^{\text {th }}, 2021$

\begin{abstract}
In this pandemic era, face-to-face learning cannot be done because the transmission of the virus is very dangerous and after all learning activities must continue, to improve the quality of education in Indonesia, therefore in this sophisticated era we must make the best use of technology for the wrong teaching and learning activities. the only way is by holding it online, but not all schools carry out learning activities with technology, there are still many who do conventional learning such as learning activities in school. The benefit of implementing online learning methods is to make it easier for teachers and students in terms of learning activities. The analysis method used is literature study. design methods that do use the concept of software engineering.
\end{abstract}

Keywords: Online Learning; Keep Learning; Information Technology

\begin{abstract}
Abstrak
Di era pandemi ini pembelajaran tatap muka tidak bisa dilakukan karena penularan virus yang sangat berbahaya dan bagaimanapun juga kegiatan belajar harus tetap berjalan, untuk meningkatkan kualitas pendidikan di Indonesia, karena itu di zaman yang canggih ini kita harus memanfaatkan teknologi sebaik mungkin demi kegiatan belajar mengajar salah satunya dengan diadakannya daring, akan tetapi tidak semua sekolah melakukan kegiatan belajar dengan teknologi, masih banyak yang melakukan secara belajar konvensional seperti kegiatan belajar di sekolahan. Penerapan metode belajar online sendiri manfaatnya adalah agar memudahkan para guru dan murid dalam hal kegiatan belajar. Metode analisa yang dilakukan yaitu studi literatur. metode perancangan yang lakukan menggunakan konsep rekayasa perangkat lunak.
\end{abstract}

Kata Kunci: Belajar Online; Tetap Belajar; Teknologi Informasi

\section{Pendahuluan}

Teknologi sangat berkembang pesat dan sangat luas. Saat ini dengan adanya jaringan yang luas, pertukaran informasi saat ini sangat cepat yang dapat akses dimana pun tidak ada batasan waktu. Internet merupakan kumpulan jaringan yang saling terhubung secara meluas dengan berbagai alat elektronik untuk mengakses internet. Contoh dari internet adalah bentuk interaksi jarak jauh yang dilakukan sesama manusia, seperti video call atau chating.

anfaat internet dapat di gunakan untuk pembelajaran berbasis web yang merupakan elearning yang sedang populer dikembangkan pada era ini oleh berbagai lembaga pendidikan. Teknologi internet yang memiliki sifat interaktif, fleksibel, dan tidak terbatas ruang dan waktu diharapkan menjadi salah satu media pembelajaran yang unggul. ( $\mathrm{R} \&$ Surjono, Pengembangan dan implementasi e-learning menggunakan moodle dan vicon untuk pelajaran pemograman web di smk, 2016)

Pada saat ini sistem ngajar mengajar masih harus menggunakan papan tulis dan spidol yang mengharuskan para siswa diharus kan hadir ke sekolah, di masa pandemic ini, sedangkan di zaman modern seperti saat ini sudah banyak aplikasi serupa yang tersedia seperti ruang guru. 
Namun fitur standar tersebut sangat kurang memenuhi kebutuhan para siswa, sebab itu sistem yang akan kami rancang diharapkan memiliki fitur tambahan yang berguna.

Belajar online yang akan kami usul kan dilakukan menggunakan perangkat elektronik dan software yang dibuat khusus, penggunaan belajar online merupakan alternatif dari kegiatan proses belajar tatap muka. salah satu sekolah telah menerapkan belajar online, namun tidak semua sekolah dilakukan dengan menerapkan sistem informasi, hanya beberapa sekolah saja yang menerapkanya, kegiatan yang dilakukan masih tatap muka seperti kegiatan belajar.

Inilah yang menjadi daya tarik kami untuk menerapkan sebuah sistem yang baru. Sebab itu perlu dilakukan analisa seperti studi lapangan, dan analisa sistem, yang dan berlanjut ke tahap selanjutnya yaitu perancangan yang akan menerapkan konsep perancangan perangkat lunak.

Hal ini dapat di pahami menjadi sebuah peluang yang bisa memberikan sumbangsih dalam meningkatkan kualitas pendidikan di Indonesia dengan meningkatnya kualitas pendidikan. Model pengembangan digunakan sebagai dasar pembuatan web berdasarkan model pengembangan perangkat lunak yaitu (Water-fall). Metode SDLC Waterfall.

\section{Metodologi}

Studi kelayakan yang akan digunakan untuk menentukan apakah pengembangan perangkat lunak layak digunakan atau dihentikan.

Faktor kelayakan yang dianalisa yaitu:

\section{a. Kelayakan teknis}

Kelayakan teknis meliputi kebutuhan yang sistem perlukan, telah tersusun dari berbagai aspek dan teknologi yang kami gunakan. Teknologi yang kami gunakan untuk pengembangan adalah teknologi yang sangat mudah didapatkan,maka dari itu secara teknis usulan keperluan sistem bias dinyatakan layak. (Al, 2007)

\section{b. Kelayakan ekonomi}

Analisa kelayakan yang mendominasi dari analisa kelayakan yang lain adalah analisa kelayakan ekonomi, tak dapat dipungkiri lagi. Motivasi pengembangan perangkat lunak pada perusahaan adalah keuntungan, dengan demikian keuntungan dan kerugian menjadi pertimbangan dalam pengembangan perangkat lunak, kelayakan ekonomi sangat berhubungan dengan berapa banyak biaya yang dikeluarkan dan kembali. (Al, 2007)

Metodologi penelitian yang akan kami gunakan adalah metode perancangan dan metode analisa. Metode analisa yang dilakukan sebagai berikut:

1) Studi pustaka, informasi yang didapatkan bersumber dari buku dan literatur yang akan ada kaitan nya dengan objek yang sedang diteliti. informasi tersebut akan kami gunakan untuk dijadikan landasan teori dan dalam menganalisa sistem.

2) Analisis sistem, yaitu melakukan analisa dari hasil yang terkumpul untuk memenuhi kebutuhan sistem. yang telah kami dapatkan, juga melakukan perbandingan sistem yang serupa yang pernah dilakukan yang menyesuaikan kebutuhan sistem, yang kami buat agar sesuai seperti yang diinginkan. (Mailasari \& Sikumbang, 2019)

3) Penelitian ini, menggunakan metodologi model Waterfall. Dipilih karena merupakan metodologi model yang clasic, sederhana dan aturan sistem yang mengalir, agar output dari tahapan sebelumnya adalah sebuah inputan ke tahapan berikutnya. Pada gambar ditujukan alur kerangka kerja penelitian yang kami lakukan ada pada tahapan model Waterfall.

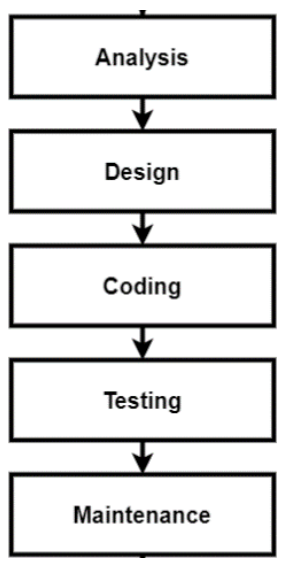

Gambar 1 Kerangka Penelitian

- Wawancara \& Observasi Lapangan Pada tahap ini, kami mendapatkan informasi dari bermacam sumber di lapangan yang ada kaitannya dengan permasalahan.

- Studi Pustaka

Di tahap ini kami mengumpulkan berbagai 
informasi yang sangat berkaitan dengan topik penelitian kami dari macam sumber. Informasi harus kami kumpulkan yaitu mengenai e-learning dengan website dan menerapkan metode Waterfall (SDLC) untuk perancangan aplikasi belajar online berbasis web.

- Analisa

Pada tahap ini kami melakukan identifikasi pada sistem untuk memenuhi apa yang dibutuhkan, mulai kebutuhan non fungsional dan fungsional, analisa ini dibagi menjadi dua bagian yaitu:

a) Analisa kebutuhan fungsional, adalah jenis kebutuhan yang prosesnya akan dilakukan oleh user. User akan mendapat kan hak hak nya seperti jadwal.

b) Analisa nonfungsional kebutuhan merupakan komponen yang harus sistem miliki. Sistem membutuh kan perangkat keras dan perangkat lunak untuk menunjang berjalan nya sistem.

- Design

Design adalah proses penggambaran pada suatu rancangan sistem pada tahap ini lanjut dari tahap analisa, pada tahap ini akan menyajikan desain, yaitu:

DFD untuk menampilkan aliran sebuah data dari sebuah sistem (biasanya sistem informasi).

- Coding

Coding adalah bagaimana cara kita menulis kode pada bahasa pemrograman, tahap ini kami mengimplementasikan suatu rancangan pada design dengan menerapkan user interface dengan bahasa PHP untuk web.

- Testing

Test itu elemen yang kritis untuk menentukan kualitas perangkat lunak yang telah dibuat yang meliputkan design, spesificate, dan codingan. Kami juga lakukan pengujian terhadap sistem menggunakan testing blackbox.

- Maintenance

Maintenance sangatlah penting bahwa sistem yang mengalami saat perubahan sudah dipergunakan penggunanya. Perubahan yang terjadi apabila terkendala kesalahan pada sistem.

- Kesimpulan dan Saran

Tahapan dari akhir model Waterfall pada penelitian ini. Kami memberikan hasil atas kesimpulan penelitian ini dan juga saran.

Tahap ini kami melakukan sesi wawancara berbagai sekolah dengan langsung mendatangi sekolah. Hasil tahapan dari wawancara adalah:

\section{Wawancara dan observasi lapangan}

- Identifikasi Masalah

Dari hasil wawancara yang kami dapat maka dapat di identifikasi permasalahan yang sedang terjadi disetiap sekolah masih melakukan sistem belajar tatap muka dimasa pandemic karena melakukan protocol kesehatan. Ini lah dapat berakibat belajar para siswa turun.

- Pengumpulan Data

Kami telah mengumpulkan data bisa yang dijadikan acuan pembuatan data aplikasi belajar online.

\section{Studi Pustaka}

Study pustaka yang kami lakukan dengan menganalisa berbagai teori E-Learning yang ada berbagai sumber terutama internet, kami memfokuskan utamanya yang berbasiskan Website, sehingga kami menjadikan panduan pada batasan-batasan dalam pengembangannya aplikasi belajar online.

\section{Analysis}

Tahap ini, analisa sistem dibagi jadi dua, yaitu:

1. Analisa Fungsional, kebutuhan yang fungsional pada belajar online ini ada 2 pengguna berbeda, ialah siswa dan guru. keduanya mempunyai karakteristik dan interaksi dengan sistem dan juga perbedaan kebutuhan informasi. Berikut adalah sekenario dari kedua pengguna tersebut:

a. Guru

- Mendapatkan jadwal dan matapelajaran dan materi dan yang diberikan admin.

- Membuat kuisioner untuk siswa atas materi yang sudah diajarkan.

- Dapat menginput nilai dari hasil kuisioner.

b. Siswa

- Dapat materi pembelajaran dan jadwal belajar dari admin

- Mendapat kuisioner dari para guru tersebut untuk mengevaluasi. 
- Dapat jawab kuisioner langsung yang terarah ke sistem

2. Analisis NonFungsional, kebutuhan nonfungsional yaitu

Berupa kebutuhan atas apa yang akan diperlukan agar belajar online dapat berjalan, yaitu Computer Monitor 1366 X 768, Mouse, dan keyboard,kecepatan internet $1 \mathrm{mbps}$.

\section{Design}

Tahap ini kami akan melakukan desain sistem menggunakan tools, yaitu:

- Data Flow Diagram (DFD) Merancang suatu sistem, maka harus terlebih duluu membuat Data Flow Diagram nya terdiri atas diagram yang konteks.

Terlihat Gambar 2 di mana diagram yang konteks adalah gambar umum sistem berjalan, di mana terdapat 2 aktor didalamnya, yaitu Siswa dan Guru.

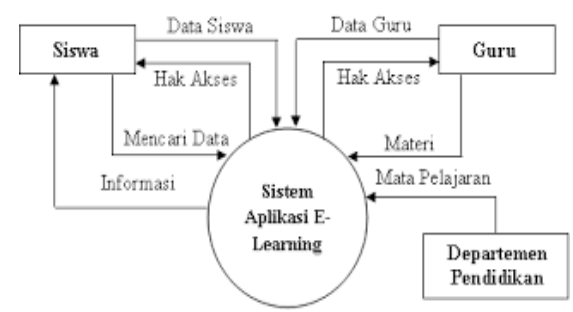

Gambar 2 Diagram konteks

- Entity Relationship Diagram

Tahap ini terlihat gambar pada ERD terdapat tiga entitas, yaitu siswa, mata pelajaran, jurusan. Entitas masingmasing memiliki atributnya. Dan juga terdapat relasi menyesuaikan hubungan antar relasi

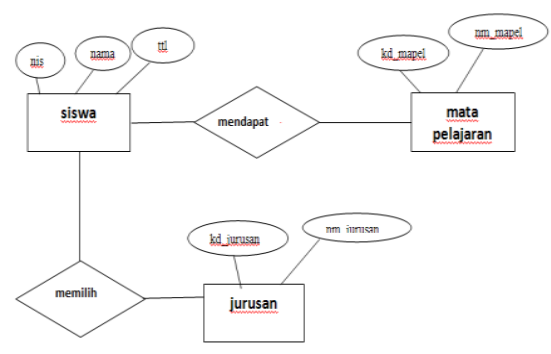

Gambar 03 Entitiy Relationship Diagram (ERD)

- Use Case Diagram Aplikasi Belajar Online
Pada aplikasi ini terdapat dua aktor yaitu Sebagai Guru dan Siswa. Guru dapat melakukan login untuk mendapatkan hak akses masuk. Guru dapat membuat kursus dan melihat jadwal. Siswa dapat melakukan login untuk mendapatkan hak akses masuk. Siswa dapat melihat jadwal dan mengikuti kursus.

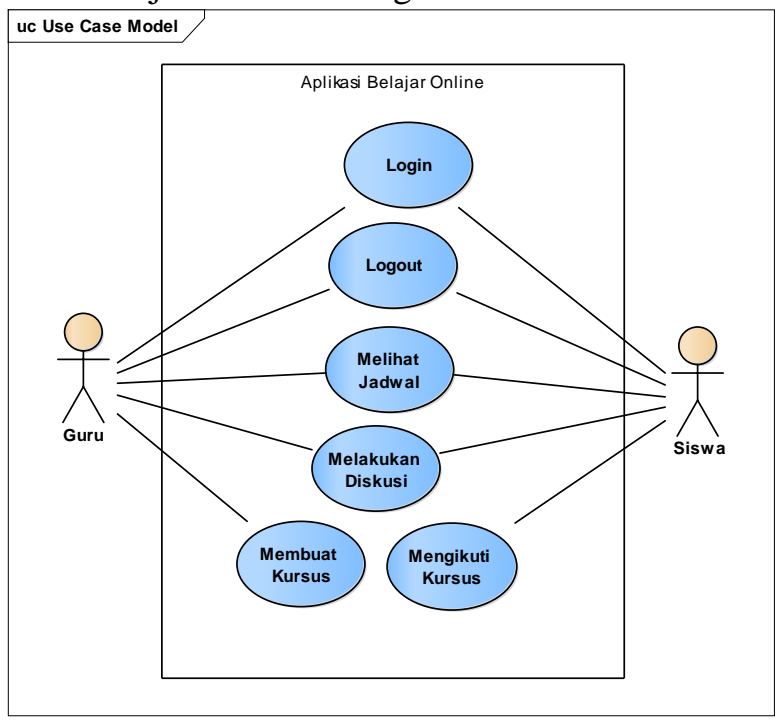

Gambar 4 Diagram use case Aplikasi Belajar Online

\section{Coding}

Tahapan ini kami melakukan implementasi atas dasar sistem yang sudah dirancang sebelumnya. Implementasi kami lakukan dengan menggunakan website, dengan Bahasa pemgrograman CSS, Javascript, Html, dan Php.

\section{Testing}

Tahapan ini kami melakukan pengetesan pada bermacam modul yang telah ada pada belajar online, kami menggunakan metode Blackbox Testing.

tahap ini testing dilakukan dengan pengujian terhadap belajar online yang sudah dikembangkan oleh kami dari sisi fungsional dan logik, dan juga memastikan bahwa semua telah teruji semua.

Dilakukan nya agar meminimalkan kesalahan juga memastikan apakah output sudah dihasilkan dengan sesuai yang diharapkan atau tidak.

Kami melakukan Pengujian Blackbox Testing mengujinya dari segi spesifikasi dan tanpa pengujian desain, source code program dengan harapan output sudah 
sesuai dengan spesifikasi yang kami butuhkan dan harapkan.

Hasil semua pengujian tombol sesuai dan dapat berfungsi baik dan hasil sudah sesuai yang telah diharapkan.

\section{Maintenance}

Pada tahap ini maintenance sangat di perlukan untuk sistem karena didalamnya ada perbaikan atau pengembangan sistem, karena sistem tidak selalu selamanya berjalan baik seperti yang telah diharapkan. Memungkinkan sistem terjadi saat dijalankan ada error kecil yang belum pernah ditemukan sebelumnya.

\section{Hasil dan Pembahasan}

Pada tahap ini terdapat tampilan screenshot hasil rancangan aplikasi belajar online.

- Menu login Pada tampilan ini terdapat menu login untuk siswa dan guru.

Guru dan siswa diharus kan login terlebih dahulu, masukan username dan password, username untuk siswa berupa nomer induk siswa (Nis) dan username guru berupa nomer unik pendidikan dan tenaga kependidikan (Nuptk).

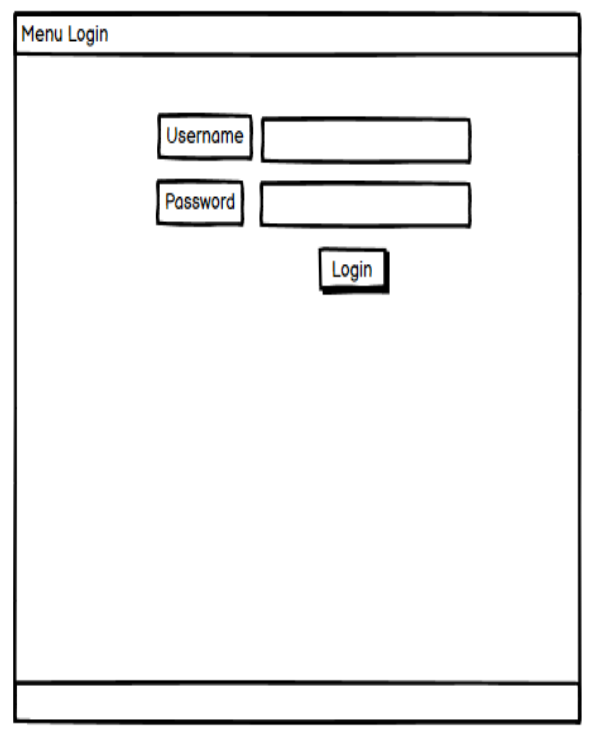

Gambar 5 Tampilan menu login.

- Menu utama

Ini adalah tampilan halaman utama aplikasi belajar online.

Pada tampilan ini guru dan siswa dapat melakukan proses pembelajaran pada menu kursus yang telah di sediakan dan juga dapat melihat jadwal pada menu kalender.

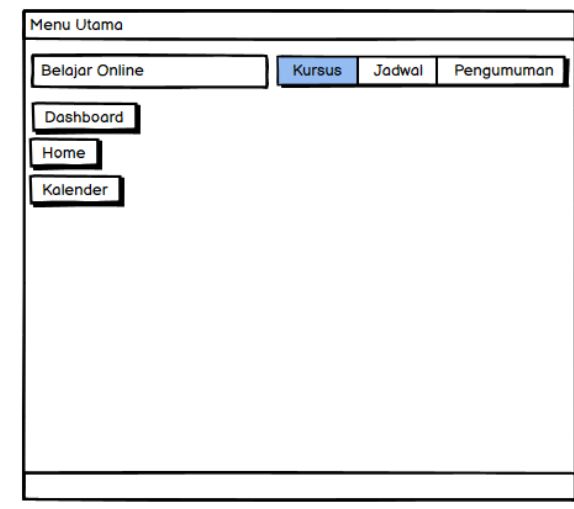

Gambar 6 Tampilan halaman utama.

\section{Kesimpulan}

Dari semua hasil analisis yang sudah kami kerjakan, bisa menyimpulkan beberapa hal sebagai berikut:

1. Belajar online ini merupakan alternatif untuk seluruh siswa dan guru untuk tetap melakukan kegiatan mengajar online di masa pandemic.

2. Aplikasi belajar online memiliki fitur yang cukup menunjang kebutuhan kegiatan proses mengajar.

Aplikasi yang dirancang ini masih butuh beberapa hal yang harus ditambahkan pada sistem semoga ke depannya dapat dikembangkan selanjutnya pada fitur di dalamnya.

\section{Referensi}

Afzal, W., \& Torkar, R. (2008). Lessons from Applying Experimentation in Software Engineering Prediction Systems. Asia-Pacific Software Engineering Conference - Workshop Proceedings, 35-43.

Al, F. H. (2007). Analisis dan Perancangan Sistem Informasi untuk Keunggulan Bersaing Perusahaan dan Organisasi Modern.

Dp Wijana. (2018). Pemertahanan dan Pengembangan Bahasa Indonesia (Indonesian Language Maintenance And Development). Maintenance and Development, 2.

Eka Wida Fridayanthie, Tias Mahdiati. (2016, Desember). Rancang Bangun Sistem Informasi Permintaan Atk Berbasis Intranet. Jurnal Khatulistiwa Informatika, 2.

Habiby, A. I., \& Yamasari, Y. (2017). Sistem Informasi Sekolah Berbasis WEB (Studi Kasus : TK Kusuma Putra Kota Mojokerto). Jurnal Manajemen Informatika, 7(2), 94-100. 
Mailasari, M., \& Sikumbang, E. D. (2019). Sistem Informasi Perpustakaan Menggunakan Metode Waterfall. doi:10.32736/sisfokom.v8i2.657

Novita Arnesi dan Abdul Hamid K. (2015). Penggunaan Media Pembelajaran Online Offline Dan Komunikasi. Teknologi Informasi \& Komunikasi dalam Pendidikan, 2.

R, H. H. (t.thn.). Pengembangan Dan Implementasi ELearning.

R, H. H., \& Surjono, H. D. (2016). Pengembangan dan implementasi e-learning menggunakan moodle dan vicon untuk pelajaran pemograman web di smk. Volume 6, No 1, Februari 2016 .

sampe hotman. (2020). Coding Jurnal Komputer . Coding Journal Komputer dan Aplikasi, 8. 